Original Research

\title{
Crop Evapotranspiration Estimations of Red Pepper Using Field Level Remote Sensing Data and Energy Balance
}

\author{
Eyup Selim Koksal ${ }^{1 *}$, Cengiz Artik², Mehmet Tasan² \\ ${ }^{1}$ Ondokuz Mayıs University, Faculty of Agriculture, Department of Agricultural Structures and Irrigation, \\ Kurupelit, Samsun, Turkey \\ ${ }^{2}$ Black Sea Agricultural Research Institute, Samsun, Turkey
}

Received: 17 January 2018

Accepted: 15 February 2018

\begin{abstract}
In this study, the energy balance approach was used to estimate evapotranspiration (ET) of red pepper plots managed with four different irrigation strategies $(100,70$, and $40 \%$ of ET, and rainfed) with drip irrigation systems in the sub-humid Bafra Plains located in northern Turkey. In order to calculate components of energy balance, hyper-spectral reflectance, infrared surface temperature, and net radiation data were measured using nadir-looking hand-held proximal sensing devices over the experimental plots. Additionally, soil moisture levels were monitored frequently with a well-calibrated neutron moisture meter and a soil water budget approach was used to calculate actual ET values. Current findings revealed that the response of red pepper crops to water stress offered a significant opportunity to detect different levels of spectral reflectance, surface temperature, and net radiation. Furthermore, statistical comparisons revealed significant relationships between measured and estimated daily ET $(r=0.92$ and RMSE $=0.83)$ and cumulative ET $(r=0.99$ and RMSE $=43.98)$ values. Estimation errors for daily and cumulative ET using the energy balance algorithm were $27 \%$ and $14 \%$, respectively. Overall, present results indicated that the energy balance algorithm with field level remotely sensed data had a great potential to estimate ET of red peppers at plot scale.
\end{abstract}

Keywords: energy balance, irrigation management, water stress, spectral reflectance, surface temperature

\section{Introduction}

Agriculture is one of the most important economic activities in Turkey. Annual potentially available water resources of Turkey are about $112 \mathrm{~km}^{3}$ [1]. More than

*e-mail: eselim@omu.edu.tr, eselimk@yahoo.com
$75 \%$ of the available freshwater resources are used for irrigated agriculture. There is an immediate need for developing new water management strategies to improve water use efficiency while developing new infrastructure to bring more land under irrigation for crop production.

Evapotranspiration (ET) transfers large volumes of water from the soil and vegetation to the atmosphere [25]. Accurate information on spatially distributed crop water use and/or ET has been a long-standing critical 
need for a wide range of applications. Quantifying crop water consumption over large areas and irrigation projects is an important issue for water rights management, water resources planning, hydrological modeling, and water regulation. At field scale, ET can be measured or estimated over a homogenous surface using conventional techniques such as Bowen ratio (BR), eddy covariance (EC), and lysimeter systems [6-7]. However, these systems do not provide spatial trends (or distribution) at regional scales [8]. While EC systems suffer from energy balance errors and require extensive fetch and tedious data preprocessing, lysimeters are expensive to build and manage and represent a small spatial scale.

Numerous remote sensing algorithms are available today for estimating magnitude and spatial trends in regional ET and crop water stress [9-21]. Basically, these algorithms depend on energy balance approach. PobleteEcheverria and Ortega-Farias used energy balance based on field level remotely sensed data to estimate ET of a vineyard [22]. Lian and Huang compared ET values estimated through different remote sensing-based models [23]. Colaizzi et al. [24] used a two-source energy balance (TSEB) model to calculate ET for cotton, gran sorghum, and corn. Drerup et al. [25] estimated winter wheat ET based on a remotely sensed spectral vegetation index. Battude et al. [26] proposed a model based on data acquired by a high spatial and temporal resolution satellite system to estimate water use of maize. During the 1990s, some ET models were developed and the majority of them consisted of detailed algorithms related to energy balance components depending on climatic data and remotely sensed data. These models include the two-source model (TSM [24, 27-31]), where the energy balance of soil and vegetation are modeled separately and then combined to estimate total LE (latent energy, or LxET, where ET is crop or land evapotranspiration and $\mathrm{L}$ is the latent heat of vaporization $2.45 \mathrm{MJ} \mathrm{kg}^{-1}$ at $20^{\circ} \mathrm{C}$ ), the surface energy balance algorithm for land (SEBAL [9, 32]), and the mapping evapotranspiration with internalized calibration (METRIC [2, 33]). Both SEBAL and METRIC use 'hot' and 'cold' pixels to develop an empirical temperature difference equation for estimating $\mathrm{H}$ (sensible heat flux to the atmosphere) [32-35]. METRIC has been applied with landsat thematic mapper (TM) data throughout the United States. Tasumi et al. [18] validated METRIC for various crops grown on weighing lysimeters located at the USDA-ARS laboratory in Kimberly, ID. Allen et al. [33] compared seasonal ET estimated for two agro-ecosystems in semi-arid Idaho: an irrigated meadow in the Bear River Basin and a sugar beet field near Kimberly, where using METRIC with lysimeter measurements resulted in $4 \%$ and $1 \%$ errors, respectively; with ET overestimation errors as high as $10 \%$ to $20 \%$. Errors in predicted monthly ET at Montpelier, ID, averaged $\pm 16 \%$, although the difference for ET sums over a four-month period was only $4 \%$. Gowda et al. [35] evaluated the METRIC in the semi-arid Texas High Plains for estimating hourly ET using lysimeter data for forage and grain sorghum managed under fully irrigated and dryland water management conditions, respectively. They reported 7 and 20\% over prediction errors for irrigation and dryland lysimeter fields, respectively. Similar evaluation studies of METRIC have been done in other semi-arid regions in the world such as Spain [36], Brazil [37], and in other parts of the world. Overall, literature review has indicated that the METRIC method had a high potential for application in semi-arid regions. In a related approach, the surface energy balance system (SEBS [38]) estimates $\mathrm{H}$ based on the contrast between wet and dry areas. A detailed review of different ET algorithms is presented in [8].

The objective of this study was to assess the ability of energy balance algorithm to estimate daily ET over red pepper crops grown under four different irrigation strategies in the sub-humid Bafra Plains located in northern Turkey. For this purpose, required data such as spectral reflectance, surface temperature, and net radiation were measured using proximal sensing techniques. Thus, the application of energy balance approaches for estimating ET under various water stress levels based on field-level remotely sensed data were evaluated with respect to ET measured by soil water balance.

\section{Materials and Methods}

A drip irrigation research project was conducted during the 2010 and 2011 red pepper (Capsicum annum) growing seasons (from mid-May to the end of September) at the Soil and Water Resources Research Center of the Black Sea Agricultural Research Institute (4136' $8^{\prime}$ 'N, $\left.35^{\circ} 55^{\prime} 8^{\prime \prime} \mathrm{E}\right)$ in Samsun, Turkey. Bafra Plains is one of the important irrigated agricultural regions in Turkey, where climate conditions are sub-humid and where most of the precipitation occurs between September and April, with an annual average precipitation of $694.0 \mathrm{~mm}$. Long-term average air temperature is $14.4^{\circ} \mathrm{C}$ with maximum and minimum temperatures occurring in August $\left(27.0^{\circ} \mathrm{C}\right)$ and February $\left(3.9^{\circ} \mathrm{C}\right)$. Average relative humidity in the Bafra Plains is $72.7 \%$ [39]. Soil texture was clay for the top $0-90 \mathrm{~cm}$ layer and underlined by clay-loam layer up to $120 \mathrm{~cm}$ depth. Plant available water (PAW) storage capacity for $0-30 \mathrm{~cm}, 30-60 \mathrm{~cm}, 60-90 \mathrm{~cm}$, and $90-120 \mathrm{~cm}$ depths were about $0.142,0.140,0.155$, and $0.154 \mathrm{~m}^{3} \mathrm{~m}^{-3}$, respectively.

\section{Drip Irrigation Experimental Design}

Four different irrigation treatments (S1, S2, S3, and S4) were applied based on soil water depletions. S1 was full irrigation, in which depleted water in the plant root zone was fully supplied. Irrigations were initiated when $30 \%$ of available moisture was depleted and soil moisture level was brought to field capacity in each irrigation. In S2 and S3 treatments, 70 and $40 \%$ of full irrigation was provided, respectively and irrigations were performed in the same day with S1 treatment. S4 
was rainfed treatment without irrigations, and irrigation treatments were applied only after crops passed the establishment period, at which point their average height was at least $20 \mathrm{~cm}$. During the establishment period, the timing of irrigation applications was scheduled based on the precipitation and observed soil water status in the root zone. Experiments were conducted in randomized complete block design with three replications. Plot dimensions were $6.0 \times 3.5 \mathrm{~m}$, and $2.0 \mathrm{~m}$ space was left between the plots. A neutron probe (model 503 DR, Campbell Pacific Nuclear, Martinez, CA) was used to measure soil moisture content of each $30 \mathrm{~cm}$ layer up to $120 \mathrm{~cm}$. An access tube was installed at the center of each plot of two replicates and $10 \mathrm{~cm}$ away from the crop row. Soil moisture measurements were made at 2-day intervals during June and September and oneday intervals during July and August for S1 irrigation treatment plots, and these measurements were used to schedule irrigations in all three (S1, S2, and S3) irrigation treatment plots. Soil moisture conditions were measured before each irrigation for use in soil water budget (SWB) calculations.

Irrigations were applied through a drip irrigation system designed and installed for these experiments, and the system had separate valves and monometers for each plot. Drippers had a discharge rate of $1.75 \mathrm{~L} \mathrm{~h}^{-1}$ and dripper spacing was $20 \mathrm{~cm}$.

\section{Red Pepper Variety and Agronomics}

"Yalova Yağlık 28" red pepper variety commonly grown in Bafra Plains was used as the plant material of the experiments. Red pepper seedlings were transplanted on May 19, 2010 and May 31, 2011, and last harvests was made on September 29, 2010 and October 6, 2011. Row spacing was $70 \mathrm{~cm}$ and on-row plant spacing was $40 \mathrm{~cm}$. Based on soil analysis for nutrients, a fertilizer program was developed and implemented for each year, separately. An average of about $100 \mathrm{~kg} \mathrm{~N} \mathrm{ha}^{-1}(50 \%$ before transplanting and $50 \%$ during growing season) and $60 \mathrm{~kg} \mathrm{P}_{2} \mathrm{O}_{5} \mathrm{ha}^{-1}$ (all before transplanting) were applied. Manual weed control was practiced throughout the growing season.

\section{Surface Temperature, Net Radiation, and Climate Data}

A total of 18 and 27 surface temperature (Ts) measurements were made between June-September period of 2010 and 2011, respectively. These measurements were made with a hand-held infrared thermometer (model Agri-Therm II, Everst Intersicence, Tustin, Calif.) for all plots between 1230-1330 h (solar noon) when there was no cloud cover. In order to cover both soil and crops within the field of view $\left(20^{\circ}\right)$ of the sensor, measurements were made from a height of $2.0 \mathrm{~m}$ above the ground level with a zenith angle of $45^{\circ}$, thus the area of field of view was $0.40 \mathrm{~m}^{2}$. The emissivity of the infrared thermometer was set as 0.98 . At least
4 measurements were made for each plot and averaged to get a single value for each irrigation treatment. Net radiation (Rn) measurements were carried out simultaneously with Ts measurements. The CNR 2 net radiometer (Kipp and Zonen Inc. Delft, Netherlands) was used for this purpose, and measurements were made for each plot by holding it at $50 \mathrm{~cm}$ above the crop canopy at the center of each plot. At least three Rn measurements were made for each plot and average values were determined for each treatment.

Climate variables such as air temperature (Ta), relative humidity $(\mathrm{RH})$, and precipitation $(\mathrm{P})$ were taken from a weather station located within the experimental station. Solar radiation, wind speed, and air pressure measurements were taken from the Bafra meteorological station maintained by the Turkish State Meteorological Service, located about $5.0 \mathrm{~km}$ from the experimental station.

\section{Surface Reflectance}

In order to calculate normalized difference vegetation index (NDVI) and albedo $(\alpha)$, we made hyperspectral surface reflectance measurements between 325-1075 nm using a spectro-radiometer (model Field Spec Pro FR, ASD, Boulder, USA). The lens that was used during the measurements had a $25^{\circ}$ field of view and the device was placed $1.2 \mathrm{~m}$ above the soil surface with a tripod to cover $0.22 \mathrm{~m}^{2}$. Three spectral measurements were made for each plot within the same day. Before the spectral measurements of each plot, solar irradiance measurements were made on a 50 x $50 \mathrm{~cm}$ spectralon panel. A total of 13 and 17 spectral measurements were made for 2010 and 2011, respectively. NDVI and $\alpha$ were calculated based on Eq. (1) given by [40] and Eq. (2) offered by [41].

$$
\begin{aligned}
& N D V I=(R 800-R 680) /(R 800+R 680)(1) \\
& \alpha=0.526 V I S+0.326 N I R+0.112(0.5 N I R)
\end{aligned}
$$

...where VIS and NIR represent reflectance in the visible (usually red wavebands) and near-infrared wavebands, and R800 and R680 are spectral reflectance measured at $800 \mathrm{~nm}$ and $680 \mathrm{~nm}$ wavelengths, respectively. In this study, average VIS and NIR reflectance were calculated using reflectance at all wavelengths between the $650-720 \mathrm{~nm}$ and $721-880 \mathrm{~nm}$, respectively.

\section{Calculating Daily ET with Soil Water Budget Model}

Red pepper ET values under different drip irrigation treatments were calculated using the general soil water budget approach as:

$$
E T=P+I \mp \Delta S+D+R
$$


...where ET is actual crop evapotranspiration, $\mathrm{P}$ is precipitation, I is the irrigation water applied, $\Delta \mathrm{S}$ is the soil moisture content difference between two consecutive measurements using a neutron moisture meter, $\mathrm{D}$ is the drainage, and $\mathrm{R}$ is the runoff (all units in $\mathrm{mm}$ ). Details related to calculating soil water budget are given in [42].

\section{Implementing Energy Balance Approaches}

In this study, ET was also estimated as a residual from the land surface energy balance equation as an instantaneous ET or latent heat flux (LE) at the time of the measurement, as shown in Eq. (4):

$$
L E=R n-G-H
$$

...where $\mathrm{Rn}$ is net radiation $\left(\mathrm{W} \mathrm{m}^{-2}\right), \mathrm{G}$ is the soil heat flux (W $\mathrm{m}^{-2}$ ), and $\mathrm{H}$ is the sensible heat flux $\left(\mathrm{W} \mathrm{m}^{2}\right)$. LE is converted into ET $\left(\mathrm{mm} \mathrm{h}^{-1}\right.$ or $\left.\mathrm{mm} \mathrm{d}^{-1}\right)$ by dividing it with the latent heat of vaporization $(\lambda)$ $\left[\lambda=2.501-0.00236(\mathrm{Ta}), \mathrm{MJ} \mathrm{kg}^{-1}\right.$ for Ta in $\left.{ }^{\circ} \mathrm{C}\right]$, density of water $\left(\rho \mathrm{w} ; \sim 1.0 \mathrm{Mg} \mathrm{m}^{-3}\right)$, and at an appropriate time constant. The sign convention for different flux terms in Eq. (4) was positive away from the surface (towards the atmosphere) for $\mathrm{LE}$ and $\mathrm{H}$, and positive toward the surface for $\mathrm{Rn}$ and $\mathrm{G}$. The $\mathrm{Rn}$ is the result of the surface energy budget between short- and long-wave radiation terms. In this study, Rn was measured using a net radiometer as mentioned above.

Ground heat flux $(\mathrm{G})$ was calculated as a function of measured $\mathrm{Rn}$, surface temperature, surface albedo, and NDVI [43]:

$$
G / R n=T s(0.0038+0.0074 \alpha)\left(1-0.98 N D V I^{4}\right)
$$

Sensible heat flux $(\mathrm{H})$ could be defined by the bulk aerodynamic resistance equation, which uses aerodynamic temperature and aerodynamic resistance to heat transfer:

$$
H=\frac{\rho a C p a\left(T_{a e r o}-T a\right)}{r_{a h}}
$$

...where $\rho$ a is air density $\left(\mathrm{kg} \mathrm{m}^{-3}\right)$; Cpa is specific heat of dry air $\left(\sim 1004 \mathrm{~J} \mathrm{~kg}^{-1} \mathrm{~K}^{-1}\right)$; Ta is average air temperature $(\mathrm{K}) ; \mathrm{T}_{\text {aero }}$ is average aerodynamic temperature $(\mathrm{K})$, which is defined for a uniform surface as the air temperature at the height of the zero plane displacement $(\mathrm{d}, \mathrm{m})$ plus the roughness length (Zoh, $\mathrm{m})$ for sensible heat transfer; and $r_{\text {ah }}$ is aerodynamic resistance $\left(\mathrm{s} \mathrm{m}^{-1}\right)$ to heat transfer from $\mathrm{Zoh}$ to $\mathrm{Zm}$ [height of wind speed $(\mathrm{U}, \mathrm{m})$ measurement]. In this study, $\mathrm{H}$ was estimated without needing to know the aerodynamic temperature value; instead, the difference between Ts and Ta was used [2] as:

$$
H=\frac{\rho a C p a(T s-T a)}{r_{a h}}
$$

...where $r_{a h}$ is calculated between two near surface heights, z1 and z2 (generally 0.1 and $2 \mathrm{~m}$ ) and a stability correction for atmospheric heat transfer based on the Monin-Obhukov stability length scale were used (L_MO, similarity theory $[2,44])$.

The instantaneous LE values for each irrigation treatment were obtained using Eq. (4), and it was converted into $\mathrm{ET}_{\mathrm{i}}$ value in $\mathrm{mm} \mathrm{h}^{-1}$ by dividing it with $\lambda$ and $\rho$ w (Eq.7). In this study, $\lambda$ was calculated through substituting Ta by Ts [2].

$E T_{i}=3600 L E /(2.501-0.00236(T s-273.15)) 106$

In this study, reference ET fraction (ETrF) was used for conversion of instantaneous ET into ETd [2]. The ETrF is the ratio of ETi to the reference ET for tall crop (ETr), which is computed from climate data for measurement time [45]. The computation of actual ETd, for each plot was performed as:

$$
E T d=E \operatorname{Tr} 24 E \operatorname{TrF}
$$

...where ETr24 is the cumulative 24-h ETr for the day $\left(\mathrm{mm} \mathrm{d}^{-1}\right)$ based on climate data. Finally, ETrF was calculated for every day of each period between two measurements made by handheld radiometers through interpolation. Seasonal cumulative ET values were calculated as the sum of ETd values.

\section{Statistical Analysis}

The energy balance-derived daily and cumulative ET values were compared with ET values derived from the soil water balance (SWB) method. Cumulative ET values were calculated for July 5-September 1 in 2010 (58 days) and June 6-September 19 in 2011 (105 days). Coefficient of correlation (r) and root mean square error (RMSE) were used in comparison of predicted daily and cumulative ET values with the measured SWB data. The $r$ describes the proportion of variability in the observed data explained by the model, and it ranges from 0 to 1 with higher values indicating a better fit (improved coefficient of determination). The RMSE of zero indicates a perfect fit, and it is usually presented as a percentage of observed mean. RMSE less than 50\% of the observed mean may be considered low.

\section{Results and Discussion}

\section{Evapotranspiration through Soil Water Balance}

Table 1 gives actual seasonal ET values for four different irrigation treatments (S1, S2, S3, and S4 plots) derived using the SWB method $\left(\mathrm{ET}_{\mathrm{SWB}}\right)$ for 2010 and 2011. The lengths of red pepper growing seasons in 2010 
Table 1. Applied amount of irrigation water, amount of rainfall, reference evapotranspiration (ETo), and evapotranspiration measured by soil water balance $\left(\mathrm{ET}_{\mathrm{SWB}}\right)$ values of four irrigation treatments for the 2010 and 2011 growing seasons.

\begin{tabular}{|c|c|c|c|c|c|c|}
\hline Year & Growing season & Irrigation Treatments & $\begin{array}{l}\text { Irrigation } \\
(\mathrm{mm})\end{array}$ & $\begin{array}{l}\text { Rainfall } \\
(\mathrm{mm})\end{array}$ & $\begin{array}{l}\text { ETo } \\
(\mathrm{mm})\end{array}$ & $\begin{array}{l}\mathrm{ET}_{\text {SWB }} \\
(\mathrm{mm})\end{array}$ \\
\hline \multirow{4}{*}{2010} & \multirow{4}{*}{$\begin{array}{c}\text { May } 19-\text { September } 29 \\
133 \text { days }\end{array}$} & S1 & 365 & \multirow{4}{*}{377} & \multirow{4}{*}{595} & 472 \\
\hline & & S2 & 266 & & & 415 \\
\hline & & S3 & 168 & & & 367 \\
\hline & & S4 & 36 & & & 294 \\
\hline \multirow{4}{*}{2011} & \multirow{4}{*}{$\begin{array}{c}\text { May } 31-\text { October } 6 \\
128 \text { days }\end{array}$} & S1 & 507 & \multirow{4}{*}{177} & \multirow{4}{*}{546} & 508 \\
\hline & & $\mathrm{S} 2$ & 360 & & & 384 \\
\hline & & S3 & 212 & & & 277 \\
\hline & & S4 & 16 & & & 162 \\
\hline
\end{tabular}

and 2011 were 133 and 128 days, respectively. Year 2010 (May 19-September 29) was a wet year with precipitation (377 mm) exceeding long-term averages (183 mm) by more than $50 \%$ for the red pepper growing period. Irrigation quantities varied between $36-365 \mathrm{~mm}$ in 2010 and between 16-507 $\mathrm{mm}$ in 2011. Seasonal $\mathrm{ET}_{\mathrm{SwB}}$ for S1, S2, S3, and S4 plots were respectively calculated as 472 , 415, 367, and $294 \mathrm{~mm}$ in 2010 and 508, 384, 277, and $163 \mathrm{~mm}$ in 2011. The actual $\mathrm{ET}_{\mathrm{SWB}}$ for S4 plot (rainfed) was about $62 \%$ of $\mathrm{S} 1$ plot in 2010 . However, actual $\mathrm{ET}_{\mathrm{SWB}}$ of S4 plot in 2011 was only $32 \%$ of the S1 plot. This is because the growing season precipitation in 2011 was close to normal $(177 \mathrm{~mm})$, and available soil moisture was less than the crop water demand.

\section{Field-level Remotely Sensed Data}

Fig. 1 illustrates variations in NDVI and $\alpha$ values for red pepper during the 2010 and 2011 growing seasons. At the time of transplanting, the NDVI values were about 0.1 for all treatment plots. As the season progressed, greater NDVI and $\alpha$ values were observed for the S1 plots, followed by the S2, S3, and S4 treatment plots. Since there was greater than normal rainfall during the 2010 growing

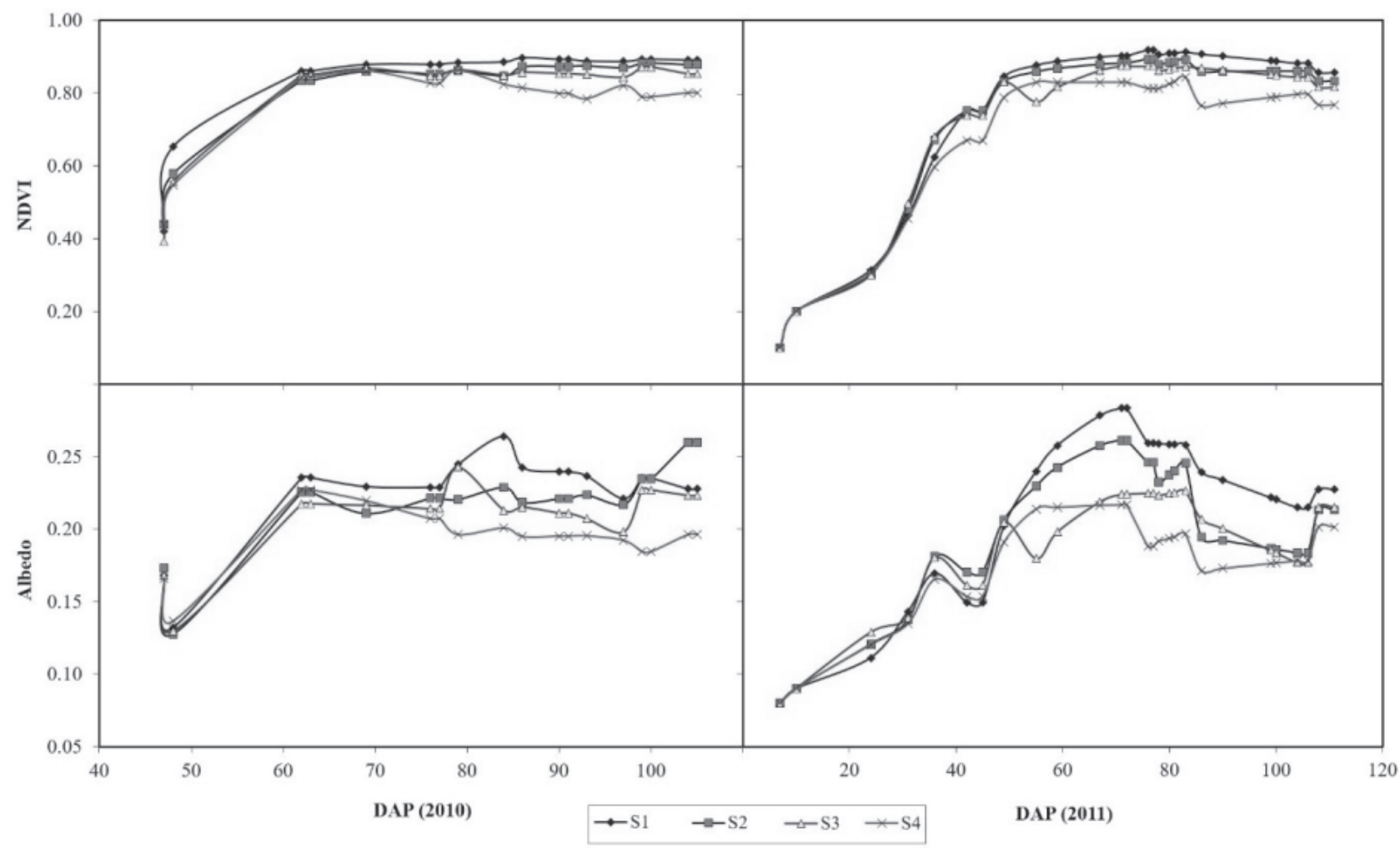

Fig. 1. Variations in normalized difference vegetation index (NDVI) and albedo $(\alpha)$ values of irrigation treatments according to days after planting (DAP) of 2010 and 2011. 


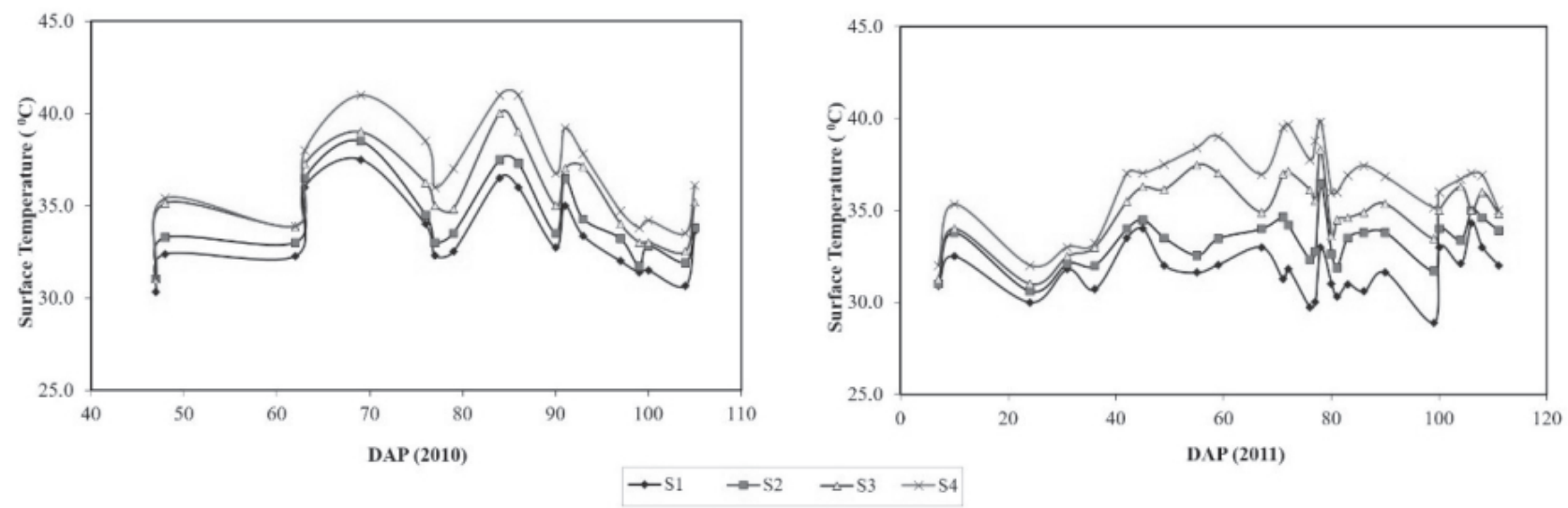

Fig. 2. Surface temperature variations throughout the measurement periods of 2010 and 2011 for each irrigation treatment.

season, magnitudes of NDVI were not significantly different from each other during the first half of the growing season. However, NDVI values in S4 (rainfed) plots varied significantly from the other treatments later in the season, where most of the crop water demand was met by irrigation. Although a somewhat similar trend was observed in 2011, the S4 plot data showed consistently less NDVI values throughout the growing season. Overall, the NDVI for rainfed plots reached at least to 0.75 in both years. Higher NDVI value (0.92) was recorded in the S1 plots during 2011. These values were consistent with the values reported for pepper in the literature [46]. Albedo $(\alpha)$ values for different treatment plots did not differ from each other during the early part of the growing season as there was not much difference in the NDVI values of different irrigation treatments. As the NDVI started differing from each other as a result of irrigation treatments, greater $\alpha$ values were in a relationship with greater NDVI values associated with more short-wave energy reflection. Overall, $\alpha$ varied from 0.1 during the early part of the season to 0.28 during the mid-season with highly vegetative crop cover over the ground. Values of $\alpha$ found in this study were within the range of values reported in the literature [47].

Fig. 2 illustrates variations of measured Ts for four irrigation treatment plots (S1, S2, S3, and S4) during the 2010 and 2011 red pepper growing seasons. In general, Ts values fluctuated between 30.3 and $43.7^{\circ} \mathrm{C}$ for vegetated surfaces. The lowest Ts values were measured for the surface of fully irrigated S1 treatment plots throughout the growing seasons due to enough transpiration from leaves and evaporation from soil surfaces. Ts values measured for S2 and S3 treatments were higher than S1 plots and consistent with irrigation levels. The highest Ts values were associated with S4 (rainfed) plots, as expected.

\section{Energy Balance Components}

Fig. 3 shows fluctuations of measured $(\mathrm{Rn})$ and estimated (H, G, and LE) components of energy balance throughout the measurement periods of 2010 and 2011.
Although trends in measured $\mathrm{Rn}$ for all treatments did not differ much from each other, larger $\mathrm{Rn}$ values were associated with highly vegetated conditions with no-water stress (S1 treatment), followed by S2. Values of $\mathrm{Rn}$ ranged from 499.0 and $727.0 \mathrm{~W} \mathrm{~m}^{-2}$ for plots with red pepper crops. The trends and magnitude in the estimated $G$ values for four red pepper treatments with different irrigation levels for 2010 and 2011 are also presented in Fig. 3. As expected, the $G$ values during the early part of the 2010 growing season were relatively smaller than in 2011 due to wetter conditions. However, estimated $\mathrm{G}$ values were found to be similar in the later parts of the 2010 and 2011 growing seasons. Greater values were associated with rainfed (S4) plots as expected. In general, $G$ values increased with water stress, which was affected by a lower canopy cover percentage. Calculated $\mathrm{H}$ values varied between nearly 0.0 and $550.0 \mathrm{~W} \mathrm{~m}^{-2}$, and the differences among the irrigation treatments were higher than those of Rn and G. Especially higher $H$ values were calculated for $S 4$ treatment, and $H$ values were consistent with water levels. According to results of LE calculations, while most of the energy absorbed as $\mathrm{Rn}$ was used by water in either plant or soil in the S1 treatment, based on water availability, the lower part of the $\mathrm{Rn}$ was distinguished for ET in S4 treatments. There were important differences between LE fluctuations of treatments and LE of S2 and S3 varied between S1 and S4 based on the ET levels.

\section{Comparison of Estimated and Measured ET}

Fig. 4 gives fluctuations of daily $\mathrm{ET}_{\mathrm{SWB}}$ and estimated ET according to $\mathrm{EB}\left(\mathrm{ET}_{\mathrm{EB}}\right)$ throughout the measurement periods of 2010 and 2011 with respect to irrigation and rainfall for each irrigation treatment separately. Although there were some differences between $\mathrm{ET}_{\mathrm{EB}}$ and $\mathrm{ET}_{\mathrm{SWB}}$, the variation trend of these two kinds of ET were very similar. Under the effect of irrigation water levels in S1 and S2 treatments, ET values had peak values during the mid-season of crop development, and in S3 and S4 treatments the ET of initial and development seasons were higher than those of mid and late seasons. Fig. 4 


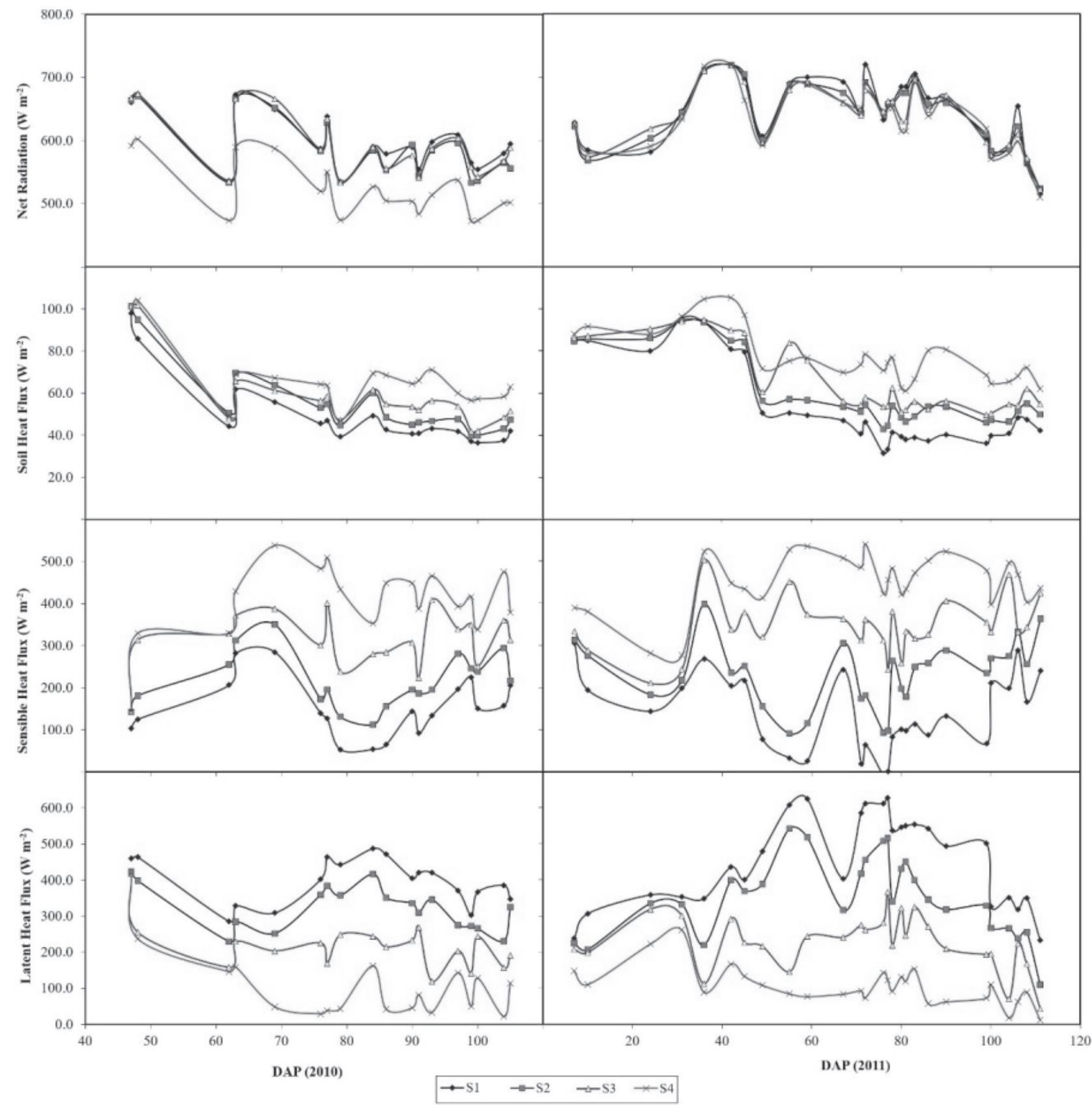

Fig. 3. Fluctuations of measured (net radiation) and estimated (soil heat flux, sensible heat flux, and latent heat flux) components of energy balance for measurement periods of 2010 and 2011 .

shows that, with an acceptable percentage of error, daily ET could be monitored by using proximal remote sensing techniques easily rather than soil water budget, which has some components difficult to monitor precisely.

The comparison of daily $\mathrm{ET}_{\mathrm{EB}}$ calculated based on remotely sensed data and energy balance algorithm with daily $\mathrm{ET}_{\mathrm{SWB}}$ of 2010 and 2011 are presented in Fig. 5. The $\mathrm{r}$ and RMSE of this comparison were 0.92 and $0.83 \mathrm{~mm}$ $\mathrm{d}^{-1}(\mathrm{P}<0.01)$, respectively. The 1:1 line in Fig. 5 indicated that the energy balance algorithm with remotely sensed data overestimated daily ET of red peppers for ET values higher than $2.3 \mathrm{~mm}$. Overall, daily ET estimation error was $27 \%$, and this percentage was higher for daily ETc values and lower than $2.3 \mathrm{~mm}$, which belonged mostly to S3 and S4 treatments (Fig. 4) with lower vegetation levels and lower crop cover ratios. Cumulative $\mathrm{ET}_{\mathrm{EB}}$ and $\mathrm{ET}_{\mathrm{SWB}}$ values of each irrigation treatment were calculated for measurement periods of 2010 and 2011 experimental years. During 2010, measurements were performed for a period between July 5 and September 1 (58 days) and for 2011 June 07 -September 19 (104 days). Performance statistics of cumulative values were greater than daily values of $\mathrm{ET}_{\mathrm{EB}}$ and $\mathrm{ET}_{\mathrm{SWB}}$ as $\mathrm{r}=0.99$ and RMSE equals $43.98 \mathrm{~mm}$. However, over $216.0 \mathrm{~mm}$, energy balance algorithm yielded higher cumulative ET values than measured values, and this over estimation reached nearly $80.0 \mathrm{~mm}$ for the highest ET level. These findings indicated that the applied algorithm of energy balance 

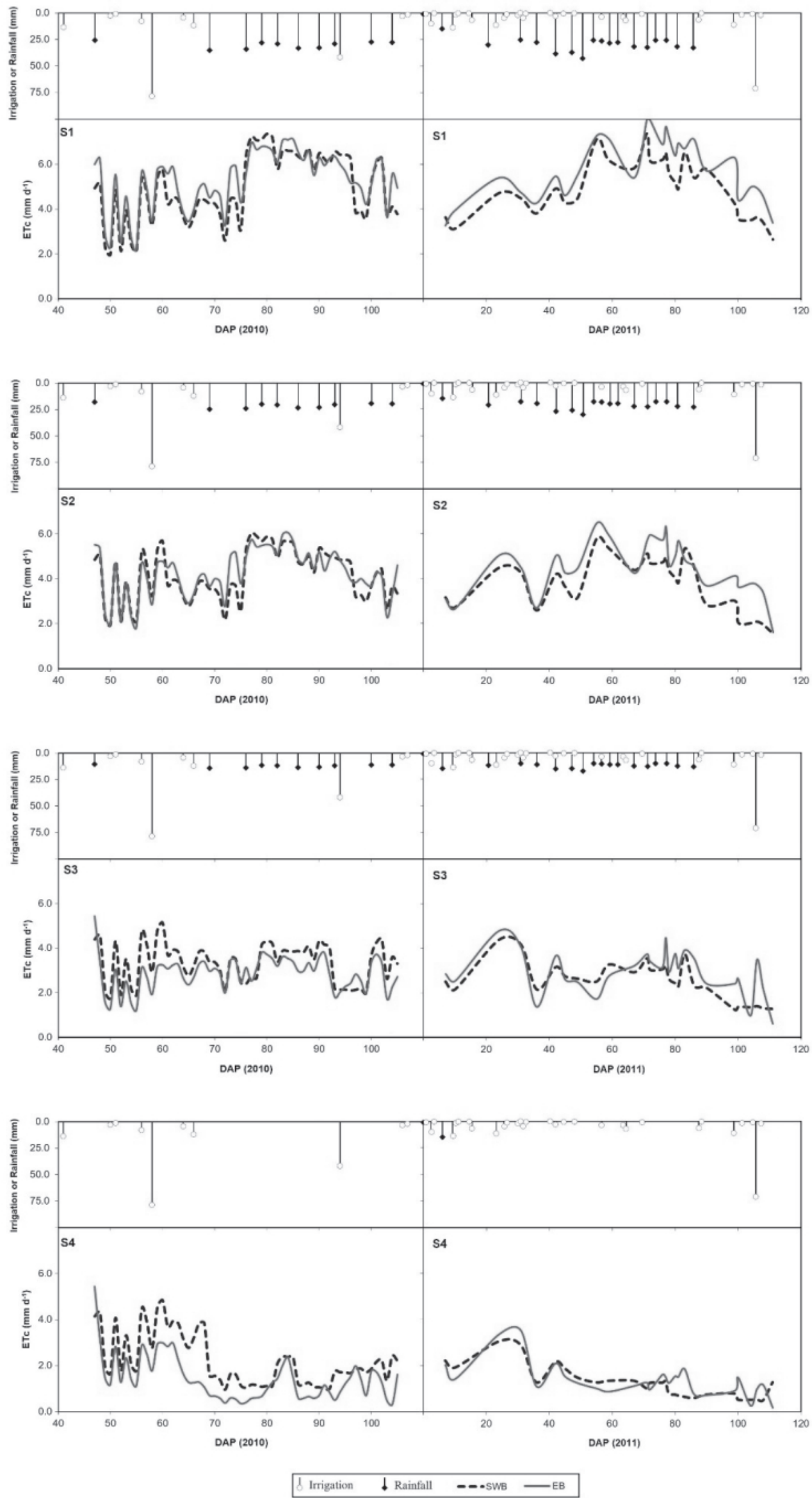

Fig. 4. Variations in daily evapotranspiration values of treatments estimated by energy balance $\left(\mathrm{ET}_{\mathrm{EB}}\right)$ and measured by soil water budget $\left(\mathrm{ET}_{\mathrm{SWB}}\right)$. 

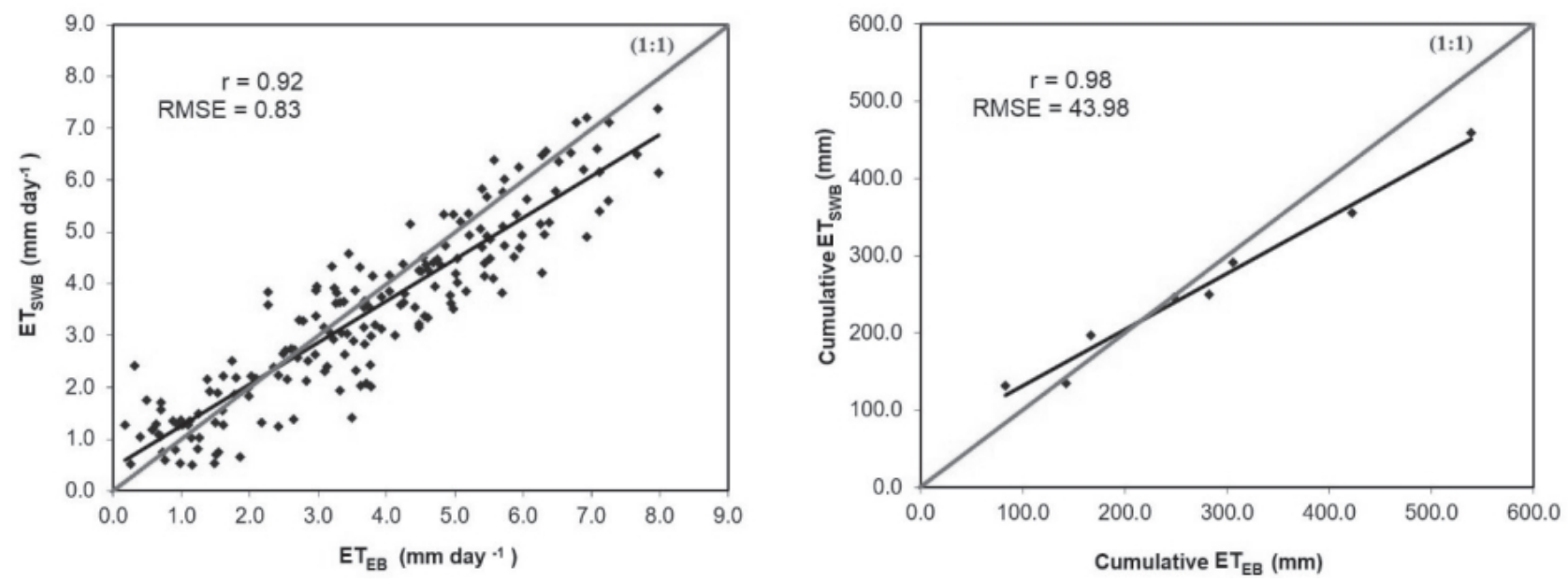

Fig. 5. Comparison of daily and cumulative evapotranspiration estimated using energy balance $\left(\mathrm{ET}_{\mathrm{EB}}\right)$ with measured values by soil water budget $\left(\mathrm{ET}_{\mathrm{SwB}}\right)$-derived measured data. Cumulative ET values were calculated for 58 days between July 05 and September 01,2010 and 104 days between June 07 and September 19, 2011.

was more sensitive to transpiration from vegetation than evaporation from soil. Also, errors related to measuring Ts, spectral reflectance and Rn, sensitivity of hand-held radiometers, stability conditions of each measurement, and bias due to calibration accuracy of soil moisture measurement sensor could be other sources of the differences between $\mathrm{ET}_{\mathrm{EB}}$ and $\mathrm{ET}_{\mathrm{SWB}_{\mathrm{B}}}$.

\section{Conclusions}

In this study, remote sensing-based energy balance algorithm was evaluated for its ability to estimate ET over red pepper crops grown under four different drip irrigation treatments at plot scale in the sub-humid Bafra Plains of northern Turkey. Measurements of surface temperature (Ts) and hyper-spectral surface reflectance in visible and near infrared wavelengths were made using hand-held instruments during 2010 and 2011 growing seasons. Additionally, red pepper ET values under different water management strategies were measured using the SWB method.

There are different indicators for determination the most appropriate irrigation time, such as stress degree day (SDD) and crop water stress index (CWSI), which depends on remotely sensed canopy temperature at the field level. Also, some of the spectral vegetation indexes could be an indicator of water stress. The water deficit index (WDI) developed by [48] for irrigation scheduling depends on both spectral reflectance-based vegetation index and surface temperature. Besides the time of irrigation, the amount of irrigation water to apply is another crucial issue for agricultural water management.

Present findings revealed that red pepper crops were quite sensitive to water stress, and physiological responses could be determined through hand-held remote sensing devices, and such measurements may offer significant tools for efficient irrigation water management. Especially variations in surface temperatures with water stress showed that infrared temperature data could reliably be used for irrigation scheduling of red peppers. We concluded that spectral vegetation index values such as NDVI could be used to determine the difference between non-water stressed and water stressed red peppers.

We also concluded, based on present findings, that energy balance approximation and remotely sensed surface temperature, spectral reflectance, and net radiation data has a significant potential to be used in estimating daily ET values for red pepper crops irrigated with drip irrigation, for plot level water management, and for the implementation of irrigation scheduling. Statistical analyses revealed significant relationships between measured and estimated ET values, and average estimation error was $27 \%$ for daily ET and $14 \%$ for cumulative ET. However, more work is needed with different crops under different agrometeorological conditions for a thorough evaluation of the application of energy balance approach with remotely sensed data at plot/field scales.

\section{Acknowledgements}

This study was supported by both Ondokuz Mayis University (PYO.ZRT.1901.10.001) and the Black Sea Agricultural Research Institute (TAGEM-BB090201H1). Many thanks to students of the Agricultural Structures and Irrigation Department of Ondokuz May1s University for their valuable fieldwork during their practice, and the field workers and laboratory staff of the Black Sea Agricultural Research Institute. The authors are also grateful to Assoc. Prof. Dr. Zeki Gökalp (a certified English translator and an expert in biosystems engineering) for his critical reading and through syntactic corrections of the manuscript. 


\section{Conflict of Interest}

The authors declare no conflict of interest.

\section{References}

1. ANONYMOUS. Available online: www.dsi.gov.tr (http:// en.dsi.gov.tr/). (accessed on 30/ 11/2017).

2. ALLEN R.G., TASUMI M., TREZZA R. Satellite-based energy balance for mapping evapotranspiration with internalized calibration (METRIC)-Model. J Irrig Drain E, 133 (4), 380-394, 2007.

3. ALLEN R.G., JENSEN M.E., Evaporation, evapotranspiration, and irrigation water requirements. ASCE MOP 70 ( $2^{\text {nd }}$ ed.). American Society of Civil Engineers, Reston, VA, 2016.

4. ALLEN R.G., PEREIRA L.S., HOWELL T.A., JENSEN M.E. Evapotranspiration information reporting: I. Factors governing measurement accuracy, Agric. Water Manage., $98(6), 899,2011$

5. ANDERSON M.C., KUSTAS W.P., ALFIERI J.G., HAIN C.R., PRUEGER J.H., EVETT S.R., COLAIZZI P.D., HOWELL T.A., CHAVEZ J.L. Mapping daily evapotranspiration at Landsat spatial scales during the BEAREX'08 field campaign, Adv. Water Resour., 50, 162, 2012.

6. WANG S., PAN M., MU Q., SHI X., MAO J., BRÜMMER C., JASSAL R.S., KRISHNAN P., LI J., BLACK T.A. Comparing Evapotranspiration from Eddy Covariance Measurements, Water Budgets, Remote Sensing, and Land Surface Models over Canada. Journal of Hydrometeorology. 16 (4), 1540, 2015.

7. LIU S., XU Z., WANG W.Z., JIA Z.Z., ZHU M.J., BAI J., WANG J. A comparison of eddy-covariance and large aperture scintillometer measurements with respect to the energy balance closure problem. Hydrol. Earth Syst. Sci. 15, 1291, 2011.

8. GOWDA P.H., CHAVEZ J.L., COLAIZZI P.D., EVETT S.R., HOWELL T.A., TOLK J.A. ET mapping for agricultural water management: present status and challenges. Irrigation Sci. 26, 223, 2008.

9. BASTIAANSSEN W.G.M., PELGRUM H., WANG J. MA Y., MORENO J.F., ROERINK G.J., VAN DER WAL T. A remote sensing surface energy balance algorithm for land (SEBAL) 1. Formulation. J Hydrol, 212-213, 198, 1998.

10. VEYSI S., NASERI A.A., HAMZEH S., BARTHOLOMEUS H. A satellite based crop water stress index for irrigation scheduling in sugarcane fields. Agr Water Manage. 189, 70, 2017.

11. EGEA G., PADILLA-DÍAZ C.M., MARTINEZGUANTER J., FERNÁNDEZ J.E., MANUEL PÉREZRUIZ Assessing a crop water stress index derived from aerial thermal imaging and infrared thermometry in superhigh density olive orchards Agr Water Manage. 187, 210, 2017.

12. ANDERSON M.C., ALLEN R.G., MORSE A., KUSTAS W.P. Use of Landsat thermal imagery in monitoring evapotranspiration and managing water resources. Remote Sens Environ. 122, 50, 2012.

13. MONTIBELLER Á.G., Estimating energy fluxes and evapotranspiration of corn and soybean with an unmanned aircraft system in Ames, Iowa. Electronic Theses and Dissertations. 416.http://scholarworks.uni.edu/etd/416. 2017.
14. LIOU Y.A., KAR S.K. Evapotranspiration Estimation with Remote Sensing and Various Surface Energy Balance Algorithms-A Review. Energies. 7, 2821, 2014.

15. ELHADDAD A., GARCIA L.A. Using Surface Energy Balance Model (ReSET) to Estimate Seasonal Crop Water Use for Large Agricultural Areas-Case Study for the Kingdom of Saudi Arabia. Presented at Ninth International Conference on Irrigation and Drainage: Improving Irrigation Water Management-Latest Methods in Evapotranspiration and Supporting Technologies. Ft. Collins, CO. October 11-14, 2016.

16. SENAY G.B., LEAKE S., NAGLER P.L., ARTAN G., DICKINSON J., CORDOVA J.T., GLENN E.P. Estimating basin scale evapotranspiration (ET) by water balance and remote sensing methods. Hydrological Processes. 25, 4037, 2011.

17. SINGH R. K., LIU S., TIESZEN L. L., SUYKER A. E., VERMA S. B. Estimating seasonal evapotranspiration from temporal satellite images, Irrig. Sci., 30 (4), 303, 2011.

18. ELHADDAD A, GARCIA L.A., CHAVEZ J.L. Using a surface energy balance model to calculate spatially distributed actual evapotranspiration. J Irrig Drain Eng 137 (1), 17, 2011.

19. TEIXEIRA A., BASTIAANSSEN W.G.M., AHMAD M.D., BOS M.G. Reviewing SEBAL input parameters for assessing evapotranspiration and water productivity for the Low-Middle Sao Francisco River basin, Brazil Part A: calibration and validation. Agric For Meteorol 149 (3-4), 462, 2009.

20. CHIROUZE J., BOULET G., JARLAN L., FIEUZAL R., RODRIGUEZ J.C., EZZAHAR J., ER-RAKI S., BIGEARD G., MERLIN O., GARATUZA-PAYAN J., WATTS C., CHEHBOUNI G. Intercomparison of four remote-sensing-based energy balance methods to retrieve surface evapotranspiration and water stress of irrigated fields in semi-arid climate. Hydrol. Earth Syst. Sci. 18, 1165, 2014.

21. GONZALEZ-DUGO M.P., NEALE C.M.U., MATEOS L., KUSTAS W.P., PRUEGER J.H., ANDERSON M.C., LI F. A comparison of operational remote sensing-based models for estimating crop evapotranspiration. Agric. For. Meteorol. 149, 1843-1853, 2009.

22. POBLETE-ECHEVERRI'A C., ORTEGA-FARIAS S., Calibration and validation of a remote sensing algorithm to estimate energy balance components and daily actual evapotranspiration over a drip-irrigated Merlot vineyard. Irrig Sci. 30, 537, 2012.

23. LIAN J., HUANG M. Comparison of three remote sensing based models to estimate evapotranspiration in an oasisdesert region. Agr Water Manage. 165, 153, 2016.

24. PAUL D. COLAIZZI P.D., O'SHAUGHNESSY S.A., EVETT S.R., MOUNCEB R.B. Crop evapotranspiration calculation using infrared thermometers aboard center pivots. Agr Water Manage. 187, 173, 2017.

25. DRERUP P., BRUECK H., SCHERER H. W. Evapotranspiration of winter wheat estimated with the FAO 56approach and NDVI measurements in a temperate humid climate of NW Europe. Agr Water Manage. 192, 180, 2017.

26. BATTUDE M., BITAR A.A., BRUT A., TALLEC T., HUC M., CROS J., WEBER J.J., LHUISSIER L., SIMONNEAUX V., DEMAREZ V., Modeling water needs and total irrigation depths of maize crop in the south west of France using high spatial and temporal resolution satellite imagery. Agr Water Manage. 189, 123, 2017.

27. DIARRA A., JARLAN L., ER-RAKI S., LE PAGE M., AOUADE G., TAVERNIER A., BOULET G., EZZAHAR 
J., MERLIN O., KHABBA S. Performance of the twosource energy budget (TSEB) model for the monitoring of evapotranspiration over irrigated annual crops in North Africa. Agr Water Manage. 193, 71, 2017.

28. COLAIZZI P.D., AGAM N., TOLK J.A., EVETT S.R., HOWELL T.A., GOWDA P.H., O'SHAUGHNESSY S.A., KUSTAS W.P., ANDERSON M.C., Two-Source Energy Balance Model to Calculate E, T, and ET: Comparison of Priestley-Taylor and Penman-Monteith Formulations and Two Time Scaling Methods. Transactions of the ASABE. 57 (2), 479, 2014.

29. SONG L., LIU S., KUSTAS W.P., ZHOU J., XU Z., XIA T., LI M. Application of remote sensing-based two-source energy balance model for mapping field surface fluxes with composite and component surface temperatures. Agricultural and Forest Meteorology 230-231, 8, 2016.

30. SONG L., KUSTAS W. P., LIU S., COLAIZZI P. D., NIETO H., Xu Z., MA Y., LI M., AGAM N., TOLK J.A., EVETT S. R., Applications of a thermal-based two-source energy balance model using Priestley-Taylor approach for surface temperature partitioning under advective conditions. Journal of Hydrology. 540, 574, 2016.

31. CAMMALLERI C., ANDERSON M.C., CIRAOLO G., D'URSO G.,. KUSTAS W.P., LA LOGGIA G., MINACAPILLI M. Applications of a remote sensing based two-source energy balance algorithm for mapping surface fluxes without in-situ air temperature observations, Remote Sens. Environ., 124, 502, 2012.

32. BASTIAANSSEN W.G.M., PELGRUM H., WANG J., MA Y., MORENO J.F., ROERINK G.J., VAN DER WAL T. A remote sensing surface energy balance algorithm for land (SEBAL) 2.Validation. J Hydrol 212-213, 213, 1998.

33. ALLEN R.G., TASUMI M., MORSE A., TREZZA R., WRIGHT J.L., BASTIAANSSEN, W.G.M., KRAMBER W., LORITE-TORRES, I., ROBISON C.W. Satellitebased energy balance for mapping evapotranspiration with internalized calibration (METRIC)-Applications. J Irrig Drain E. 133 (4), 395, 2007.

34. TASUMI M., TREZZA R., ALLEN R.G., WRIGHT J.L. U.S. Validation tests on the SEBAL model for evapotranspiration via satellite. In: Proceedings of $54^{\text {th }}$ IEC meeting of the international commission on irrigation and drainage (ICID) Workshop remote sensing of ET for large regions, 17 Sept (2003) Montpellier, France. 2013.

35. GOWDA P.H., HOWELL T.A., ALLEN R.G. Deriving hourly surface energy fluxes and ET from Landsat TM data using METRIC. Proceedings of the The $17^{\text {th }}$ William T. Pecora memorial remote sensing symposium - The future of Landsat imaging, American Society of Photogrammetry and Remote Sensing, November 16-20, Denver, CO. 7, 2008.

36. SANTOS C., LORITE I.J., ALLEN R.G., TASUMI M. Aerodynamic parameterization of the satellite -based energy balance (METRIC) model for ET estimation in rainfed olive orchards of Andalusia, Spain. Water Resour Manag. 26 (11), 3267, 2012.

37. FOLHES M.T., RENNÓ C.D., SOARES J.V. Remote sensing for irrigation water management in the semi-arid Northeast of Brazil. Agr Water Manage. 96 (10), 1398, 2009.

38. SU Z. The surface energy balance system (SEBS) for estimation of turbulent heat fluxes. Hydrol Earth Syst Sci. 6, 85, 2002.

39. ANONYMOUS. https://mevbis.mgm.gov.tr/mevbis/ui/ index.html\#/Workspace (accessed 25/7/2016).

40. TUCKER C.J. Red and photographic infrared linear combinations for monitoring vegetation. Remote Sens Environ. 8, 127, 1979.

41. BREST C.L., GOWARD S.N. Deriving surface $\alpha$ measurements from narrow band satellite data. Int $\mathrm{J}$ Remote Sens. 8, 351, 1987.

42. KOKSAL E.S, TASAN M., ARTIK C., GOWDA P. Evaluation of financial efficiency of drip-irrigation of red pepper based on evapotranspiration calculated using an iterative soil water-budget approach. Sci Hortic. 226, 239, 2017.

43. BASTIAANSSEN W.G.M. SEBAL-based sensible and latent heat fluxes in the irrigated Gediz Basin, Turkey. J Hydrol. 229, 87, 2000.

44. FOKEN T. 50 Years of the Monin-Obukhov similarity theory. Boundary-Layer Meteorology. 119 (3), 431, 2006.

45. ASCE-EWRI. The ASCE Standardized Reference Evapotranspiration Equation. Technical Committee report to the Environmental and Water Resources Institute of the American Society of Civil Engineers from the Task Committee on Standardization of Reference Evapotranspiration. ASCE-EWRI, 1801 Alexander Bell Drive, Reston, VA, 173, 2005.

46. YILDIRIM M., DEMIREL K., BAHAR E. Effect of restricted water supply and stress development on growth of bell pepper (Capsicum Annum L.) under drought conditions. Agro Crop Sci J, 3 (1), 1, 2012.

47. EVETT S.R. Water and energy balances at soil-plantatmospheric interfaces. In:Warrick, A. W. (Ed.). The Soil Physics Companion. CRC Pres, Boca Raton, FL, 128, 2002.

48. MORAN M.S., CLARKE T.R., INOUE Y., VIDAL A. Estimating crop water deficit using the relation between surface - air temperature and spectral vegetation index. Remote Sens Environ. 49, 2463, 1994. 
